\title{
Capital controls: a tool to protect an economy under pressure? The cases of Cyprus, a eurozone member, and Iceland
}

\section{Georgios Gad*}

International Business Department,

Care Direct S.A.,

8 Dervenakion Street, Dafni,

17235, Athens, Greece

and

MBA Programme,

School of Social Sciences,

Hellenic Open University,

Parodos Aristotelous 18, 26-335, Patra, Greece

Email: georgiosgad@gmail.com

*Corresponding author

\section{Emmanuel Petrakis}

Department of Economics, University of Crete,

Gallos University Campus,

Rethymnon, Crete, GR 74100 Greece

Email: petrakis@uoc.gr

and

MBA Programme,

School of Social Sciences,

Hellenic Open University,

Parodos Aristotelous 18, 26-335, Patra, Greece

\begin{abstract}
This paper considers the effectiveness of capital controls as a protective action. We analyse the recent cases of Iceland and Cyprus and examine the extent to which the controls on free capital movement delivered the outcome that motivated their imposition in each country. The methodology used examines main macro-economic indicators and attempts to locate significant variations pre and post capital controls. The results indicate that controls were only partially successful. In Iceland they did not manage to control the pressure over foreign exchange rate. In case of Cyprus controls achieved only partially to control outflows. Belonging to the eurozone was not proven to be a negative factor for success of the measures in Cyprus.
\end{abstract}

Keywords: capital controls; capital controls effectiveness; capital flows; financial crisis; eurozone; international economics; Cyprus; Iceland. 
Reference to this paper should be made as follows: Gad, G. and Petrakis, E. (2020) 'Capital controls: a tool to protect an economy under pressure? The cases of Cyprus, a eurozone member, and Iceland', Int. J. Decision Sciences, Risk and Management, Vol. 9, Nos. 1/2, pp.106-128.

Biographical notes: Georgios Gad is holding the position of Near East Regional Manager in the advertising sector. He holds a BA in Mathematics from the School of Sciences, University of Athens. He received his MSc in Marketing and Communication with New Technologies from Athens University of Economics and Business and his MBA from the Hellenic Open University.

Emmanuel Petrakis is a Professor of Industrial Organisation and Policy in the Department of Economics, University of Crete, where he has taught for the last 19 years and is Head of the Business Economics and New Technologies Lab (BENETeC). He holds a BSc in Naval Engineering from the National Technical University of Athens, 1980, a BA and MA in Economics from Athens University of Economics and Business in 1983 and 1985 respectively.

\section{Introduction}

Free mobility of capital, especially between emerging and advanced economies, is generally considered beneficial for all parties involved, as it reduces the cost of capital, provides financing opportunities and establishes a friendly environment for an economy to grow (Haldane, 2011; IMF Strategy, Policy, and Review Department, 2011). This widely accepted view led many economies during the 1990s to liberalise their capital accounts (Edison and Reinhart, 2000) and avoid controls on capital flow. Reality though has demonstrated that this strategy could also have negative consequences. Asian crisis of 1997 caused a shift in the debate but it was after the subsequent 2008's Leman brothers collapse that the discussion over the usefulness of capital controls has been exonerated.

Iceland in 2008 and Cyprus in 2013, following the path of other countries in the mid-90's, entered a cycle of extreme financial turbulence that finally led them to impose a series of measures as a last resort to confront with a disastrous situation. In this paper we examine thoroughly these two capital control episodes using methods proposed by the literature, attempting to evaluate whether, and to which extent, the imposition of controls over capital flows was successful or not. Iceland follows the pattern of Malaysia or Thailand in 1997-1998 (Edison and Reinhart, 2000), while Cyprus is an unprecedented event as it was the first country of the eurozone that applied such financial policy.

This research faces a few limitations. First, the results presented are linked with the specific incidents (Cyprus and Iceland) and should not be considered as 'stylised facts'. The term 'stylised facts' describes empirical findings that due to their consistency across a wide range of markets and periods, are generally considered to be undeniably true. Also, due to their generality, they are often qualitative (Sewell, 2011). Second, both countries imposed capital controls during a period of extreme pressure and overall turbulence and not as a strategic financial policy during normal conditions. Thus, it is hard to separate the consequences that are due to the measures and those that are due to the financial crisis. Finally, the results are mainly driven with the use of descriptive statistics and not with the use of extensive econometric analysis. 
In the sequel, we briefly present the objectives and types of capital controls, the restrictions imposed by the eurozone that affect their techniques, and we demonstrate how one could measure their effectiveness. The sequence of events that led to capital controls in Cyprus and Iceland and the research hypotheses follows. We then outline the methodology used to control hypotheses and assess the effectiveness of measures in each country, focusing primarily on main macroeconomic indicators and attempting to filter them through the eurozone framework in case of Cyprus. Finally, we summarise our conclusions and discuss possible extensions of our analysis.

\section{Capital controls background}

According to Neely (1999) capital control is a policy designed to limit or redirect capital account transactions. By using it, a government, central bank or other regulatory authority, aims to limit or regulate the flow of foreign capital in and out of the domestic economy in other countries' capital accounts. These measures could be applied generally or per sector, e.g., the financial sector or a specific industry. Moreover, the measures could be applied in a way that affects all flows or part of them, depending on the duration or the type of the flow, e.g., debt, bonds, equity, short-term vs. medium and long-term investments and foreign exchange trades.

\subsection{Objectives and types of capital controls}

Magud et al. (2011) have clustered the problems that lead to the imposition of capital controls in four main categories that they called the 'Four Fears':
a appreciation
b hot money
c large inflows
d loss of monetary autonomy.

It is quite hard to give a broad definition of controls, since they take many forms and have different intended effects according to the type of capital movement they are targeting (Bakker, 1996). We could summarise them as capital inflows and outflows objectives.

It is rare to find these measures applied by governments as a precaution. In most cases controls come as a non-popular way to deal with uncomfortable financial circumstances. Often countries have to deal with an unfavourable balance of payments status - deficit or surplus - that translates to imbalance in the current account. Capital flows restriction accompanied by a fixed exchange rate and targeted monetary policy could manage to reduce or increase the demand of foreign assets and thus to eliminate the balance of payments deficit or surplus, respectively.

Another reason for the imposition of capital controls is the real appreciation of the exchange rate as a result of excess in capital inflows. The latter leads to a rise of domestic goods and assets prices making them less competitive and less appealing for export. 
Countries like Brazil, Chile and Columbia that faced this problem have chosen to block the capital inflows and engage in capital controls to solve it. It should be noted that according to the impossible trinity, policy makers are not able to achieve simultaneously more than two of the following macroeconomic goals (Burda and Wyplosz, 2005): Aafixed exchange rate, an independent monetary policy and free capital movement (in other words absence of capital controls).

Apart from balance of payments and real appreciation, economists recently postulated another theory highlighting another circumstance under which such measures could be useful. The 'theory of the second best' proposes that tax or quantitative restrictions could work in a way that improves the economic welfare and regulates or corrects market distortions otherwise difficult to be corrected (Neely, 1999). Capital controls represent the best of the last resort measures aiming to deal with the destabilising results that the international capital flow causes, in a financial system already carrying by nature intrinsic financial distortions ${ }^{1}$ (Mishkin, 1998).

Finally, the distinction of controls is based on whether they are imposed on inflows or outflows. On top of this, Neely (1999) suggested that controls on inflows should be divided into controls on short-term inflows, e.g., bank deposits and money market instruments, and controls on long term (exceeding one year) inflows, e.g., direct investment and equity, because each of them has a different purpose. In general controls on inflows lead to higher interest rates and decrease the supply of money, while controls on outflows allowed lower interest rates and significantly higher money growth that in any other possible scenario (Marston, 1995). Capital controls are also categorised as "price-based" when they limit asset transactions through price mechanisms (taxes), or "quantity-based" when they work via quantity controls (quotas or outright prohibitions).

\subsection{Legality and contradictions under the EU framework}

Within EU laws and treaties, capital controls are not easily justified. It is not only a matter of legality in accordance to the membership's obligations but also a matter of theoretical and practical consistency, especially when it comes to the eurozone members, since capital controls contradict to the very sense of the monetary union (Linklaters, 2013). The Treaty on the Functioning of the European Union (Europa.eu, 2012) clearly states in Article 63(1) of chapter 4: "Within the framework of the provisions set out in this Chapter, all restrictions on the movement of capital between Member States and between Member States and third countries shall be prohibited."

The basic advantage and ability to move money, without any capital restrictions, from one bank to another, within the currency area, represents the most important characteristic of the eurozone. If any member of the currency union proceeds by imposing capital restrictions then a euro in the imposing state has no longer the same value with a euro held by any other state bank in the monetary union (Wolff, 2013). Cyprus represents an unprecedented incident in the eurozone area which defies the union guidelines and at the same time, creates the circumstances for a parallel, unofficial monetary policy within the union from a member state (Linklaters, 2013). 


\subsection{Measuring the effectiveness of capital controls}

Unfortunately, there is no unified, commonly accepted framework of analysis leading to justifiable results over the macroeconomic consequences of controls. Each country under inspection has a significantly different economic status as a starting point and the time of control imposition varies. Eventually, the researcher faces a significant heterogeneous environment to work on. In addition although being a single policy instrument, the policy objectives vary. Eventually, there are many opinions and definitions on how a success story is defined. Magud et al. (2011) set four questions to measure controls' success:

a "Did capital controls reduce the volume of capital flows?"

b "Did capital controls alter the composition of capital flows?"2

c "Did capital controls reduce the real exchange rate pressure?"

d "Did capital controls allow for a more independent monetary policy?"

Additionally, they reviewed more than 30 papers regarding inflows indicating that controls seem to make the monetary policy more independent, alter the composition of capital flows, reduce real exchange rate pressures but fail to reduce the volume of capital inflows. In contrast little evidence exists indicating, except maybe from the Malaysian crisis in 1997, that capital controls achieve their basic goals when it comes to capital outflows.

\section{Case studies and chronicle of events}

We present now the cases of Cyprus (a member of the European Union and eurozone) and Iceland (a member of the European Free Trade Area but not the European Union) and postulate our research hypotheses. Both concern primarily capital control imposition on outflows and are expected not to achieve their objectives (Magud et al., 2011). We underline the fixed exchange rate and the ECB regulated monetary policy for Cyprus.

\subsection{The Cypriot bank crisis}

Cyprus went into a recession during 2009, affected by the mortgage crisis in the US. Between 2010 and 2012, Cyprus' economic growth became very weak, failing to reach again the levels it had before 2009 (The Global Economy, 2017). Commercial property indicators lost $30 \%$ of their value (RICS, 2012) and the non-performing loans indicator increased by 6.1\% in 2011 (World Bank, 2017), suffocating the Cypriot banking system.

On March 9, 2012, a restructuring of the Greek debt held by private investors (mainly banks) took place. The PSI process attempted to relief Greek state of its debt burden. As a result $97 \%$ of privately held Greek bonds corresponding to $€ 197$ billion received a $53.5 \%$ haircut of the face value (principal) of the bond. This amount corresponded to an approximately $€ 107$ billion reduction in Greece's debt stock (ESM, 2017). Cypriot banks at that point represented a significant investor and fund lender to Greek economy and because of the PSI process, they have witnessed severe losses. On March 13, 2012, Moody's downgraded Cyprus's credit rating to speculative status. Cyprus government was advised to recapitalise its local banks to cover the losses created by Greece's debt swap 
(PSI). Finally on June 25, 2012, the Cypriot government requested the assistance of the European Stability Mechanism (ESM) to finance its debt. Fitch downgraded the Cyprus bonds status to $\mathrm{BB}+$ and eventually disqualified them from being accepted as collateral by the ECB (Wilson, 2012).

After months of negotiations Cyprus received a $€ 10$ billion loan by the Euro group, European Commission (EC), European Central Bank (ECB) and International Monetary Fund (IMF). The agreement predicted a plethora of austerity measures. Cyprus should shut down Cyprus Popular Bank, one of its largest systemic banks and merge it with Bank of Cyprus. Its assets, including unsecured deposits over $€ 100,000$, would be used to cover part of its debts. Moreover, depositors in Bank of Cyprus with more than $€ 100,000$ would lose part of their deposits. No insured deposit of $€ 100,000$ or less would be affected (Strupczewsk and Breidthardt, 2013).

During the last stage of negotiations the Cypriot government shut down all banks for a period of two weeks to avoid a possible bank run. After the measures were announced, on March 27, 2013, on the day that banks reopened to the public, a series of capital controls were activated to stop cash outflow. A $€ 300$ withdrawal maximum limit per day per individual and $€ 500$ per day per company was imposed. Money transfers were limited to $€ 5,000$ per month and travellers' cash were limited to $€ 1,000$. This was the first time in the times of EU that such a measure was applied (The Economic Times, 2015).

In Cyprus, at least during the first weeks of imposition, capital controls affected severely business activity, since it was almost impossible for all companies to settle their liabilities towards their employees and suppliers. Gradually and as the country returned to normality the restrictions were lifted step by step, starting with allowing the opening of accounts once again in May, 2014 and the total lift of capital controls on April 6, 2015 (The Economic Times, 2015).

\subsection{The Icelandic financial crisis}

In 2008 all three privately owned commercial banks of Iceland faced severe difficulties to refinance their short-term debt and a run of deposits to the Netherlands and UK. Lehman Brothers collapsed on 15 September 2008, resulting to a worldwide liquidity shortfall and evaporation of interbank lending (Baldursson and Portes, 2013). This framework led to the default of all three banks and a major economic and political turmoil. Iceland's banking system collapse was the largest that any country in history has ever experienced if we compare it to the size of its economy (The Economist, 2008). As a result, Iceland during 2008-2011 went through a severe economic depression and political unrest (IMF, 2015).

On 29 September 2008, the Central Bank of Iceland, in light of Glitnir Bank's collapse, announced its nationalisation by state acquisition of $75 \%$ share (Baldursson and Portes, 2013). Finally, some days later as a result of a series of unsuccessful attempts to secure international funding to stabilise the banking system, mainly due to its huge size (more than 11 times the national GDP), the Central Bank of Iceland withdrew its efforts to save the banks and focused on stabilisation of Krona exchange rate and limit capital outflows. Over the week 29 September to 3 October the exchange rate depreciated by $10 \%$ and the stock exchange felt by $20 \%$ (Baldursson and Portes, 2013).

On 6 October 2008, at 11:18 pm the Parliament enacted Emergency Legislation Act $125 / 2008$ to stabilise the situation. The government guaranteed all domestic deposits in 
Icelandic banks and imposed strict capital controls. Moreover, CBI engaged into a sovereign debt package from the IMF and the Nordic countries and secured a US\$5.1 bn in order to finance a budget deficit and to restore the collapsed banking system (Baldursson and Portes, 2013). The IMF led international support program was activated on 24 October 2008 and remained active until 31 August 2011. The strict capital controls that were imposed in November 2008 were lifted on 14 March 2017 (Alderman, 2017).

\subsection{Conclusions and research hypotheses}

The chronological structure clearly indicates that both countries proceeded with capital controls on the verge of total state failure. The decision was taken as a last resort measure and the main objective was to buy governmental authorities with time to confront the situation in a safer, less turbulent environment by proceeding with the needed transformations of the economy. Using Magud et al. (2011) set of questions, we shall examine the effectiveness of controls in each county separately and compare the results. The basic hypotheses in each country are presented in Table 1.

Table 1 Research hypotheses per county

\begin{tabular}{lcc}
\hline Ho hypotheses & Iceland & Cyprus \\
\hline The controls reduced the volume of capital flows & $\mathrm{H}_{1}$ & $\mathrm{H}_{5}$ \\
The controls altered the composition of capital flows & $\mathrm{H}_{2}$ & $\mathrm{H}_{6}$ \\
The controls reduced real exchange rate pressures & $\mathrm{H}_{3}$ & N/A \\
The controls made monetary policy independent & $\mathrm{H}_{4}$ & $\mathrm{H}_{7}$ \\
Belonging to a monetary union is a negative factor for success & N/A & $\mathrm{H}_{8}$ \\
\hline
\end{tabular}

The hypothesis of the exchange rate pressure does not apply for Cyprus since it belongs to the eurozone and does not have a local currency. We should also highlight that although Cyprus is unable (by default) to apply an independent monetary policy (this is mainly driven by the European Central Bank) still controls create the necessary microenvironment to bypass the control of the ECB and apply a 'local' policy. Thus hypothesis $\mathrm{H}_{7}$ shall be examined.

\section{Research methodology}

Time series data were provided by the Thomson-Reuters data pool, the Central bank of Iceland and the Central Bank of Cyprus. Priority was given on daily data for each of the macroeconomic indicators, given the need for continuous data streams for the proper execution of selective statistical tests. When access to daily data was not possible, monthly and quarterly observations were used to calculate basic descriptive statistics.

The basic method used to examine the validity of the research hypothesis is the comparison of the macroeconomic indicators before and after the announcement of capital controls. The data period for Cyprus, split into two sub-periods before and after 27 March 2013, starts on January 2008, the month that Cyprus joined the eurozone, and ends with the lift of capital controls in 6 April 2015. The data period for Iceland, split into two 
sub-periods before and after 9 October 2008, starts in January 2006 and ends in 14 March 2017 with the end of capital controls.

In both cases part of the available time series was excluded from the analysis. Specifically, for Cyprus data prior to the euro era were not included since the economic policies before and after the adoption of the euro currency vary significantly and ignoring this fact could lead to misleading results. We have chosen though to use a relative large period before the actual event of capital controls imposition (five years) given the fact that 2008 was the year that the financial crisis escalated, leading in combination with other parameters to the Cypriot crisis. In Iceland we have excluded data prior to January 2006. The period after January 2006 is long enough to cover observations related to Iceland's crisis period, avoiding to be too extended to potentially generate biased results affected by parameters unrelated to the controls or the financial crisis. Moreover, this period allows us to have at least 30 observations to perform a t-test, in case of monthly available statistics. Concerning daily data we have excluded the observations before 1 January 2007, since the financial crisis started in 2007 and the sample is big enough for our analysis. It should be stated that the existing literature does not indicate how much time before and after the imposition of capital controls should be examined for best results.

The analysis of the monthly and quarterly data is focusing mainly on the movement of foreign exchange reserves and capital flows. The analysis of daily data examines the changes occurred in the values of important economic indicators, such as interest rates, foreign exchange rates, bid-ask spreads on foreign exchange, and the spreads of the governmental bonds. It should be noted that the analysis and the conclusions based mainly on the observation of charts and descriptive statistics is categorised as low according to the degree of methodological rigour (Magud et al., 2011). We have thus tried to extend our analysis using methods that increase the analysis categorisation to medium level. A variety of empirical tests was employed to explore the effectiveness of capital controls. Concerning quarterly data, we analyse charts produced by each measure and their means' difference, without performing a t-test, given their discrete nature. On monthly data, we apply tests for the equality of moments aiming to discover significant differences in basic descriptive statistics before and after the imposition of capital controls.

For the macroeconomic indicators on daily data, we perform tests on the equality of moments and changes in persistence locating changes in behaviour of key financial variables, as in Edison and Reinhart (1999). Autocorrelation on time series applied to increase the degree of methodological rigor. Moreover, we aim to identify if the daily values of the macroeconomic indicators affect the values of the following day. The autocorrelation function with one day delay is the following:

$$
R(t-1, t)=\frac{E\left[\left(X_{t}-\mu_{t}\right)\left(X_{t-1}-\mu_{t-1}\right)\right]}{\sigma_{t-1} \sigma_{t}}
$$

If the function $R$ is well defined meaning that the mean exists, the variance is not zero or infinite, its value must lie in the range $[-1,1]$, with 1 indicating perfect correlation and -1 indicating perfect anti-correlation. 


\section{Control of research hypotheses}

\subsection{Evidence from charts and monthly data}

Starting our analysis with Iceland, Figure 1 includes plots of data concerning deposits, foreign exchange reserves, interest rates, and the exchange rates. All charts are divided into two parts, before and after the imposition of capital controls. It is obvious that deposits dropped dramatically over $50 \%$ the last weeks before the imposition of capital controls as a result of the significant run on deposits from the non-residents during the whole September 2008, resulting to the collapse of Landsbanki and Glitnir. With capital controls the deposits leaks in the banks were blocked and the deposits were stabilised. Foreign exchange reserves dropped initially after the imposition of controls but soon after started to gain volume. Nevertheless, it was not before October 2009 that their volume started to increase significantly reaching 420 billion euros compared to the 400 billion euros during the end of October 2008. Interest rates did not respond directly after the controls. Just before the imposition of capital controls deposit rates reached $15 \%$ before dropping to $11.5 \%$ initially after the controls and then jumped again for several days to $17.5 \%$. Gradually by the second semester of 2009 the rates have fallen to the pre-crisis period levels averaging below $10 \%$. Concerning the ISK/euro exchange rate, during the first semester of 2008, ISK started depreciating significantly against the euro and until October 2008 ISK lost almost $65 \%$ of its value. The controls initially controlled the depreciation rate but just like the interest rates it was not before the second semester of 2009 that the exchange rate was stabilised. It worth mentioning that due to the failure of Iceland to reach a fast agreement with its creditors and the extended negotiations, the ISK/euro exchange rate remained in significantly higher rates comparing to pre-crisis levels. It appears that capital controls did not improve immediately Iceland's performance but rather in the long term, given two-year long negotiations with its creditors and the negative referendums towards the agreement. Long term data suggest that capital controls contributed in the stabilisation of the economy instead of harming it.

Figure 2 illustrates similar data for Cyprus. Deposits in Cyprus significantly dropped over the first months after the imposition of capital controls mainly because of the deposit levy on Cypriot accounts that reached almost $47.5 \%$ for shareholders, bondholders, and depositors with more than 100,000 euros in the two largest banks. Total decrease reached almost $10 \%$ between March and July 2013. The deposits started to increase again after the removal of capital control in 2015. Foreign exchange reserves continued to drop after the imposition of capital controls with a significant rate losing more than $25 \%$ in the first three months of capital controls imposition. Following the deposits trend line, exchange foreign reserves started to increase again near the end of capital controls and soon after their removal. Interest rates in 2012-2013 averaged at 1.1\% while in 2015 the same overnight deposit interest rates averaged below $0.5 \%$ close to the eurozone average rates (in Section 5.3 we present more evidence from descriptive statistics in comparison to Iceland facts). The industrial production year on year appears to increase after the controls reaching by mid-2014 the 2010 levels. 
Figure 1 Iceland's basic macroeconomic indicators' charts
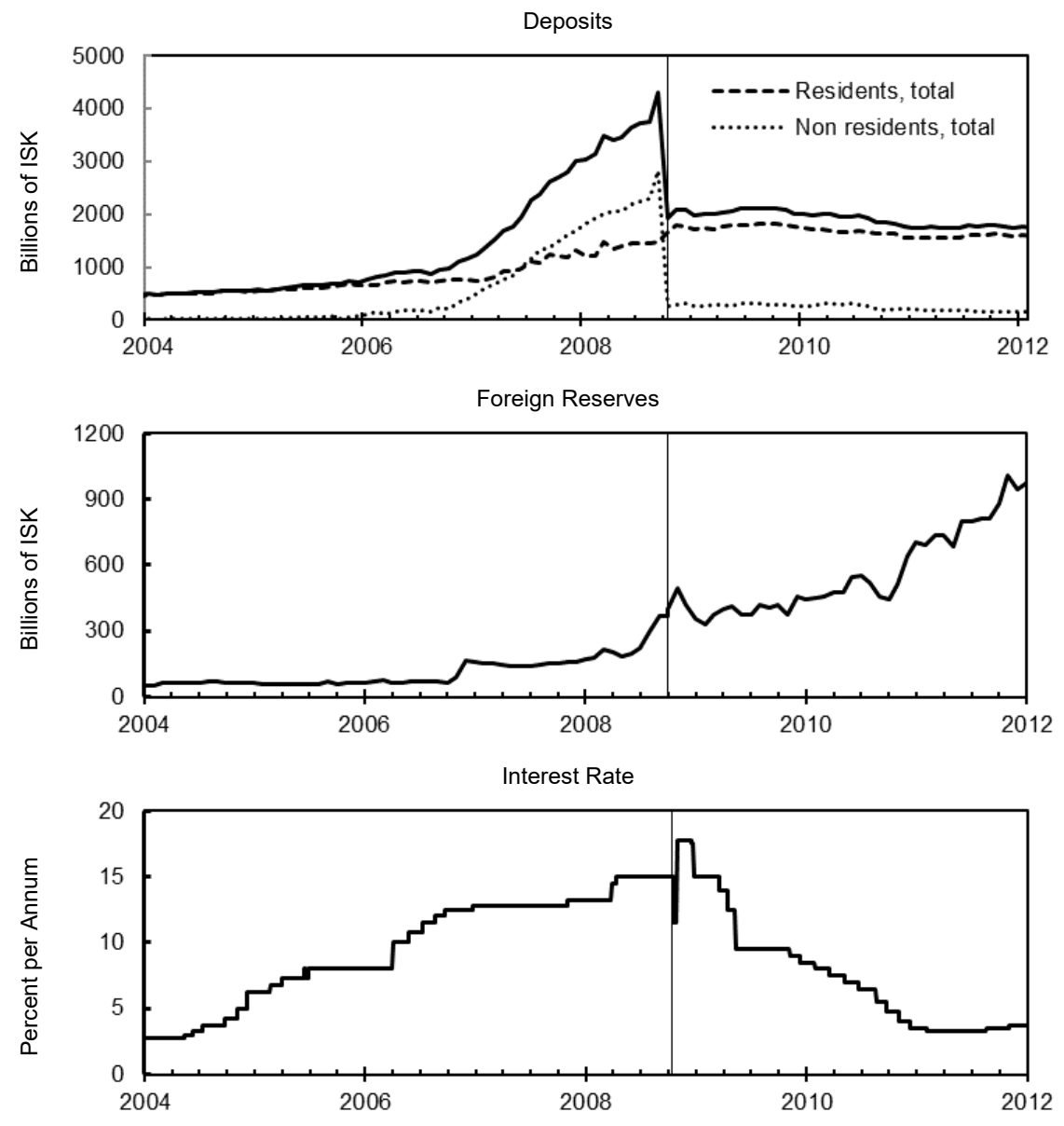

Foreign Exchange Rate

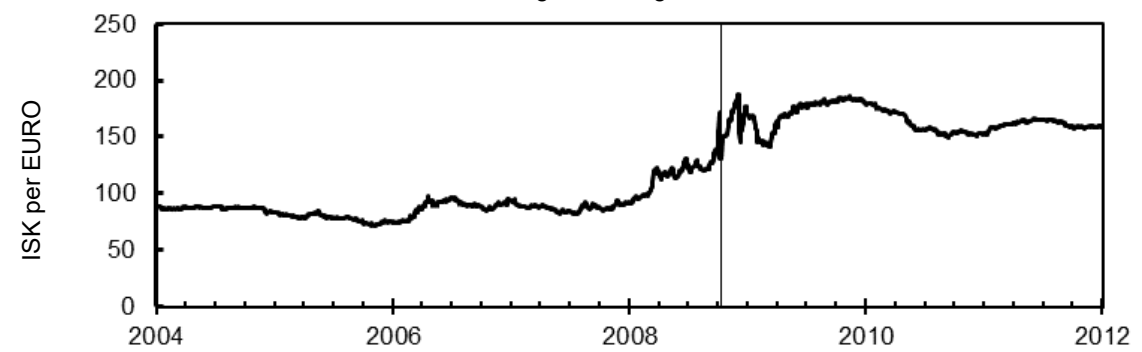


Figure 2 Cyprus's basic macroeconomic indicators' charts
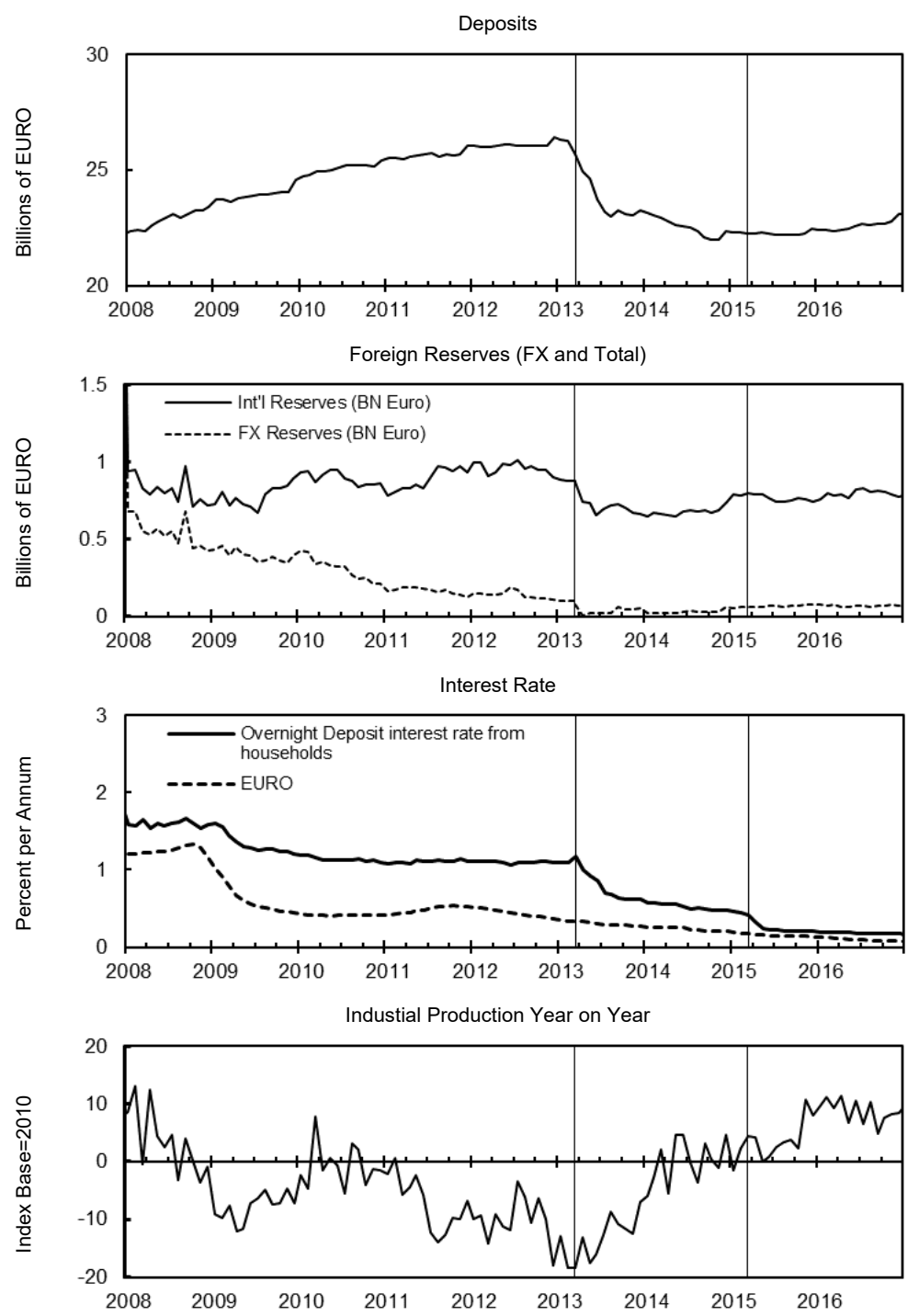

Table 2 and Table 3 present the descriptive statistics for foreign reserves, deposits and balance of trade for the two countries. For Cyprus, Table 3 includes also the monthly interest rates and the onshore-offshore deposit rate spread, since daily observations were not available. Starting with foreign exchange reserves, it appears that in Iceland (Table 2) the average level of foreign reserves is higher during the control period and the recorded difference is statistically significant. Nevertheless, foreign exchange reserves appear to be more variable after capital controls' imposition. In contrast in case of Cyprus (Table 3) foreign reserves as an average are lower during the control period and less variable in comparison with Iceland. The results are once again statistically significant. The findings indicate that capital controls concerning foreign exchange reserves volume succeeded in their role in Iceland but failed in Cyprus. 
Table 2 Iceland: descriptive statistics for monthly data

\begin{tabular}{lcccccc}
\hline Variable & $\begin{array}{c}\text { Mean no } \\
\text { controls }\end{array}$ & $\begin{array}{c}\text { Mean } \\
\text { control } \\
\text { period }\end{array}$ & $\begin{array}{c}\text { Equality in } \\
\text { means } \\
\text { t-test } \\
\text { probability }\end{array}$ & $\begin{array}{c}\text { Std. dev. } \\
\text { no } \\
\text { controls }\end{array}$ & $\begin{array}{c}\text { Std. dev. } \\
\text { no control } \\
\text { period }\end{array}$ & $\begin{array}{c}\text { Equality } \\
\text { in } \\
\text { variance } \\
\text { test }^{5}\end{array}$ \\
\hline $\begin{array}{l}\text { Foreign exchange } \\
\text { reserves }\end{array}$ & 143.805 & 591.369 & $0.000^{*}$ & 69.924 & 168.729 & $0.000^{*}$ \\
$\begin{array}{l}\text { Deposits } \\
\quad \begin{array}{l}\text { Deposits } \\
\text { change (net) }\end{array}\end{array}$ & $2,066.936$ & $1,818.849$ & $0.101^{* *}$ & $1,109.919$ & 134.060 & $0.000^{*}$ \\
$\begin{array}{l}\text { Balance of trade } \\
\quad\end{array}$ & -9.095 & 2.725 & $0.000^{*}$ & 7.109 & 8.843 & 0.159 \\
$\quad \begin{array}{l}\text { Exports } \\
\quad \text { Imports }\end{array}$ & 26.369 & 48.289 & $0.000^{*}$ & 8.866 & 6.521 & $0.022^{*}$ \\
\hline
\end{tabular}

Notes: $*$ indicates significant results at $5 \%$ level and $* *$ indicates significance at the $10 \%$ level. ${ }^{4}$ control period is from October 2008 to March 2017. ${ }^{5}$ reported test is based on F-test two-tailed methodology.

Table 3 Cyprus descriptive statistics for monthly data

\begin{tabular}{lcccccc}
\hline & Mean no & $\begin{array}{c}\text { Mean } \\
\text { control } \\
\text { controls }\end{array}$ & $\begin{array}{c}\text { Equality in } \\
\text { means } \\
\text { t-test } \\
\text { probability }\end{array}$ & $\begin{array}{c}\text { Std. dev. } \\
\text { no } \\
\text { controls }\end{array}$ & $\begin{array}{c}\text { Std. dev. } \\
\text { no } \\
\text { control } \\
\text { period }\end{array}$ & $\begin{array}{c}\text { Equality } \\
\text { in } \\
\text { variance } \\
\text { test }\end{array}$ \\
\hline Foreign exchange reserves & 0.865 & 0.686 & $0.000^{*}$ & 0.089 & 0.028 & $0.000^{*}$ \\
Deposits & 24.769 & 23.005 & $0.000^{*}$ & 1.219 & 0.917 & 0.125 \\
$\quad$ Deposits change (net) & 0.065 & -0.160 & $0.000^{*}$ & 0.118 & 0.283 & $0.000^{*}$ \\
Balance of trade & -420.681 & -268.500 & $0.000^{*}$ & 72.875 & 110.514 & $0.009^{*}$ \\
Exports & 102.408 & 190.882 & $0.000^{*}$ & 18.356 & 79.350 & $0.000^{*}$ \\
Imports & 523.090 & 459.382 & $0.003^{*}$ & 74.221 & 100.582 & $0.059^{* *}$ \\
Interest rate & 1.270 & 0.615 & $0.000^{*}$ & 0.225 & 0.187 & 0.368 \\
Change in interest rate & -0.012 & -0.027 & $0.098^{* *}$ & 0.048 & 0.049 & 0.865 \\
Onshore - offshore spread & 0.618 & 0.362 & $0.000^{*}$ & 0.187 & 0.147 & 0.963 \\
\hline
\end{tabular}

Notes: $*$ indicates significant results at $5 \%$ level and $* *$ indicates significance at the $10 \%$ level. ${ }^{8}$ control period is from April 2013 to March 2015. ${ }^{9}$ reported test is based on F-test two-tailed methodology.

Concerning the deposits volume in Iceland (Table 2), the average volume is higher before the imposition of capital controls and the difference is statistically significant at a $0.1 \%$. This is a result to be expected given the huge deposits run from the non-residents a month before the imposition of capital controls. On the other hand though, the capital controls seem to stabilise the deposits since their volume appears to be significantly less variable after the controls. A result not to be expected though, is the fact that deposits continue to decline after the capital controls (the deposits average monthly change is negative after the controls), although the latter is not statistically significant. In line with the fact that the volume is significantly less variable after the controls, the average change is also significantly less variable, demonstrating a fixed volume of deposits. The deposits volume in Cyprus also declines after the imposition of the controls and although 
stabilised, the deposits average daily change is also significantly negative, indicating a failure of controls to aboard a further loss of deposits from the banking system. In both cases capital controls fail to protect fully deposits level but again in Iceland deposits are more stable.

Regarding balance of trade, it appears that both countries during the controls have confronted their deficit position. In Iceland the situation is surprisingly different with the trade deficit to change after the controls to trade surplus (Table 2). In Figure 5 we can see that by the time the controls were imposed the deficit turned into surplus. Exports continued rising and their pace did not slow down by the controls. Imports volume has dropped and frozen initially in the first two years; yet, in the long term they also increased but in a slower pace in comparison to the exports. All the results are significant at 0.05 concerning their difference. Exports are significantly less variable indicating a solid and strong growth. The results are in line with the increase of foreign reserves after the capital controls imposition in Iceland during the same period. Table 3 indicates similar results for Cyprus although the trade balance did not turn into surplus. Imports decreased significantly indicating a decline in capital outflows. Exports also increased significantly. We should highlight though, that compared to Iceland, all trade indicators in Cyprus were significantly more variable after the capital controls imposition, indicating an unstable situation month on month. An attentive observer could also realise the above by observing Figure 5 and focusing on Cyprus' balance of trade chart. The results indicate a significant influence of control over trade and therefore over the trade related capital flows.

As mentioned, we will complement the monthly data analysis by adding some descriptive statistics and evidence about Cyprus interest rates. It should be highlighted that since Cyprus belongs to the eurozone, interest rate should follow the policy of the ECB. Nevertheless, Cyprus used capital controls to bypass in a way ECB authority and was able to manipulate onshore interest rates. Eventfully, as presented in Table 3, there was a significant drop in the average deposit interest rates during the control period. The interest rates appear to be less variable but not significantly. Moreover, after the imposition of capital controls onshore interest rates have fallen immediately with the Cypriot overnight households deposit rates to be closer to the average eurozone rates. Again the spreads are less variable but not significantly.

To sum up, capital controls seem to work a bit better in Iceland given the rise of foreign exchange reserves. On the other hand, given the fact that Cyprus is a country belonging to eurozone, foreign exchange reserves in foreign currency are of less importance. In both countries capital controls did not stop fully deposits leakage but in general the leakage was controlled and especially in Iceland the decrease was manageable. In both countries the controls helped the correction of balance of trade but in Iceland this change was stronger and less variable.

\subsection{Evidence from quarterly data and capital flows}

Capital controls should alter and reduce the capital flows in order to be considered successful. Expanding our analysis beyond the impact of controls on deposits, foreign exchange reserves and balance of trade that give an indication about the behaviour of capital flows, we have focused on the financial account of the two countries. The access 
only to quarterly data for both countries does not allow us to test the equality of moments before and after the imposition of capital controls and to check the significance of the results. Nevertheless, Figure 3 and Figure 4 that present the quarterly flows in each country, help us identify the overall trend of flows before and after the imposition of capital controls. Moreover, Table 6 measures the average capital flows as percentage of GDP per quarter before and after the imposition of capital flows.

Figure 3 Iceland's capital flows' charts
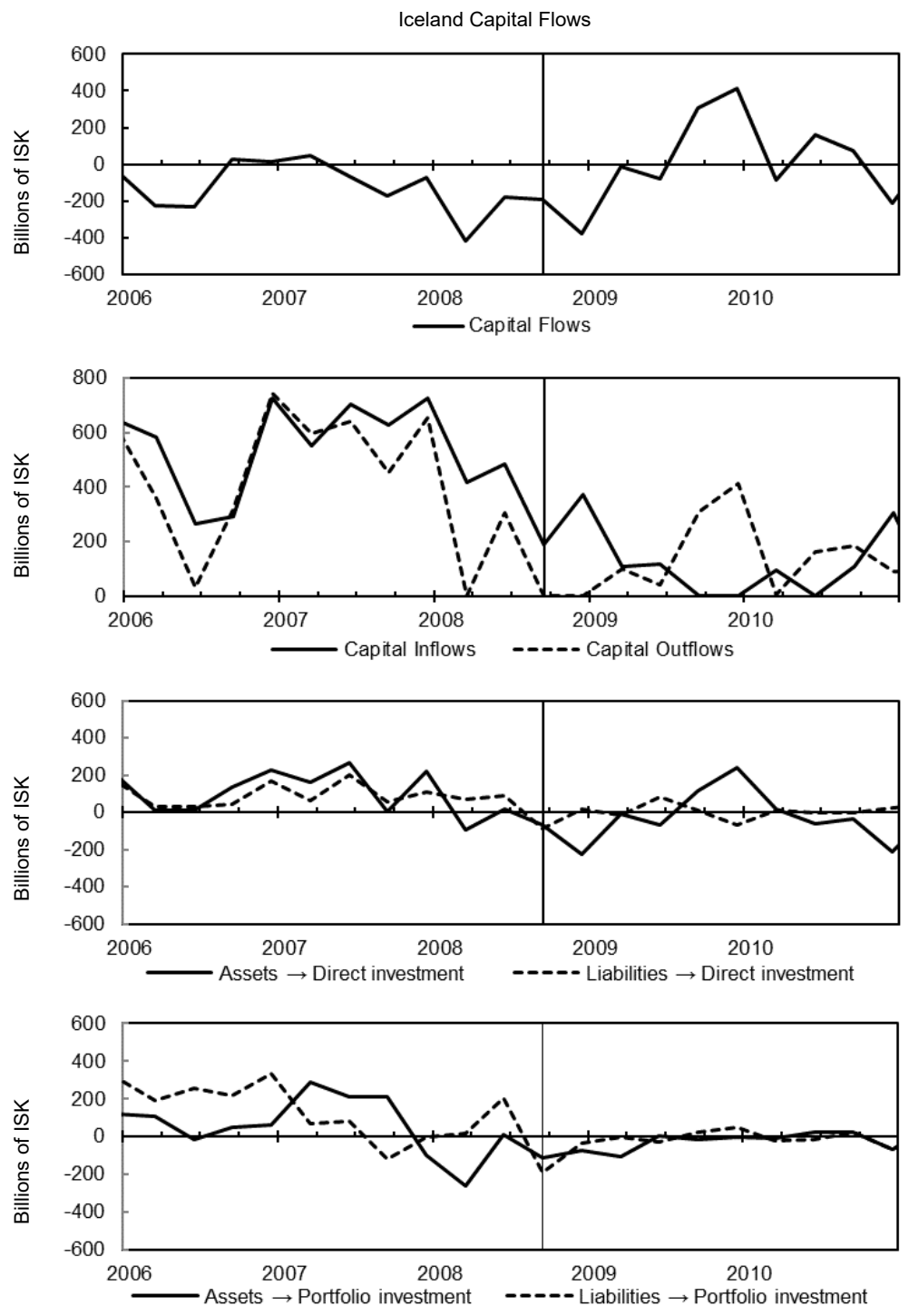
Figure 4 Cyprus' capital flows' charts
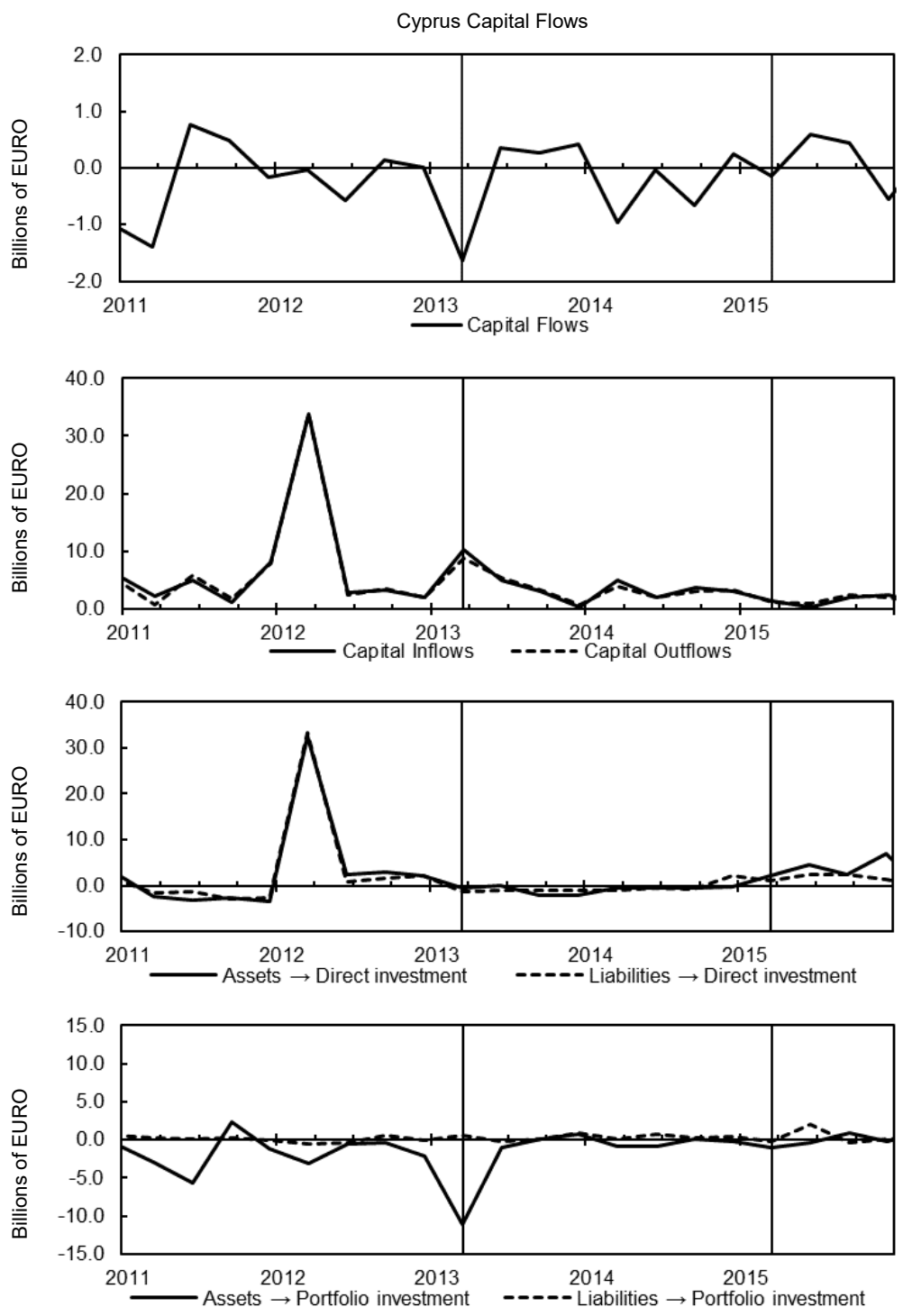

Before proceeding with the analysis, we should note that capital flows (capital and financial account) are split into direct investment net flows, portfolio investment net flows, financial net derivatives, other investment and reserve assets net flows. According to BPM6 any positive value on the financial account indicates net lending and any negative value indicates net borrowing. Our analysis focuses on private capital flows and specifically on FDI and FPI flows. Any positive value on the FDI/FPI liabilities indicates an increase on the investments that foreign investors have on a country (positive inflow) and any negative value indicates a disinvestment (negative inflow). Any positive value on the FDI/FPI assets indicates an increase on the investments of a country abroad (positive 
outflow) and any negative indicates a disinvestment and therefore repatriation of capital (negative outflow). The data acquired are based on asset/liabilities methodology (OECD, 2014). Errors and omissions are not taken into consideration in our analysis.

Figure 3 depicts that in 2007 Iceland experienced an incremental inflow of capital turning into a net borrower. The inflow continued even after the imposition of capital controls and only decreased in volume in the start of 2009. On the other hand, net outflows with the imposition of capital controls reached zero level and remained zero during the last quarter of 2008. Table 6 also indicates that the average inflows and outflows per quarter as a percentage of Iceland's GDP decreased enormously after the imposition of capital controls and Iceland changed its position from a net borrower $(-0.39$ of GDP) to a net lender (0.05 of GDP).

Analysing the direct investment chart in Figure 3, we see that the last quarter before the capital controls there has been a significant disinvestment of capital from foreign investors, which continued smaller in volume even during the first quarter after the capital controls' imposition, with a decreasing rate though. Similarly, the analysis of portfolio investment liabilities also indicates a significant disinvestment of capital from foreign investors. Surprisingly, direct investment (assets) and portfolio investment (assets) have a negative value before and after the imposition of capital controls (first two quarters), indicating a repatriation of capital from resident investors (inflow). This trend could be linked with the directions of the Icelandic government to repatriate capitals in a last attempt to support the local economy. The record high deposit rate (Figure 1) before and after the imposition of capital controls also supports this argument. Average values of FDI and FPI as a percentage of GDP (Table 6) also demonstrate that capital controls led residents to repatriate their investments and non-residents to disinvest from the local economy. An exception is inward FDI that remained as an average positive (0.03), although lower than before the controls, indicating the potentials of the Icelandic industry.

Summing up, the imposition of capital control in Iceland has altered significantly the composition and the volume of capital flows. It managed the first months to drop net outflows to zero which was one of the main objectives given the enormous outflows witnessed the last month before the imposition of capital controls due to the bank run of deposits. These findings combined with the previous observations on deposits and foreign exchange reserves volume, indicate that capital controls in Iceland were extremely effective when it comes to the desideratum of capital flows decrease and alteration. Eventually $\mathrm{H}_{1}$ and $\mathrm{H}_{2}$ are confirmed.

On the other hand, the analysis of net capital flows in Cyprus (Figure 4) leads to a different conclusion. A quarter before the imposition of capital controls there was a significant inflow of capital, mainly due to the liquidation of matured foreign portfolio investments by Cyprus' residents during this period, as indicated by the negative outflow of portfolio investment by residents (assets). At the same time, there was a significant outflow due to deposits escape as seen in Figure 2. Capital outflows, although lower in volume, did not stop even after the imposition of capital controls. Table 6 indicates that the average quarterly net capital inflows and outflows as a percentage of GDP in Cyprus decreased, but less than in Iceland. Moreover, they did not reverse their volume, as in Iceland, leaving Cyprus to its traditional position of net borrower after capital controls. 
Breaking down capital flows and focusing on the direct investment chart (Figure 4), it seems that the last quarter before the capital controls there has been a disinvestment of capital from foreign investors, which continued during the whole period of capital controls. Inward FDI started increasing again only the last quarter before removing capital controls. Not surprisingly direct investment (assets) by residents followed the same pattern. In contrast, portfolio investment liabilities increase just before capital controls and remain positive for the first quarter after the controls. We should highlight at this point that during the first quarter after the imposition of capital controls there was a significant inflow of capital due to the IMF loan (approx. 3 bin Euro) affecting significantly total inflows. Moreover, the capitalisation of a significant volume of deposits in the two systemic banks as part of the bailout agreement reflected significantly on flows after controls. Going back to Table 6, average values of FDI and FPI as a percentage of GDP in Cyprus demonstrate that capital controls led residents to repatriate their investments and non-residents to disinvest from the local economy in a far more aggressive rate than in Iceland. An exception is inward FPI that remained as an average positive (0.06), indicating the potentials of Cypriot financial service industry.

To sum up, capital controls imposition in Cyprus targeted mainly to aboard deposits outflow until completing the bailout agreement, since levy on deposits played a significant role on this. On that part controls achieved their target but it is not clear if the contribution of controls was in general vital for the Cyprus economy as concerns the capital flows. In general, capital controls did alter capital flows composition but the significant volume of IMF loan and the deposits bailout could distort the results. Eventually $\mathrm{H}_{5}$ is partially confirmed while $\mathrm{H}_{6}$ is confirmed.

\subsection{Evidence from daily data}

In Section 2, we have discussed what theory predicts concerning the behaviour of selected key economic indicators and financial variables following the introduction of measures against free capital mobility. In this section, we will check the validity of our hypothesis using daily data. We will analyse the behaviour of daily interest rates and changes in interest rates in Iceland (the analysis for Cyprus given the monthly availability of data was done in Section 5.1), stock returns, exchange rate changes, bid-ask spreads on foreign exchange (where applicable), yield spreads of t-bonds versus German bonds, and onshore-offshore interest rate differentials (where relevant). Similarly to Section 5.1, for each of these time series, we provide descriptive statistics (mean and standard errors) followed by tests for the equality of first and second moments between free capital mobility and the capital control period in each of the inspected countries. In addition, a correlogram applied in individual sub-periods, for each of the time series of the variables, with one day lag $(t-1)$ is also used to explore whether the change in policy (controls) is responsible for the change in persistence of shocks. The aim of this test is to compare the different periods and assess the extent to which any observed changes in the key variables come as a result of crisis rather than the imposition of capital controls. Tables 4 and 5 present the results for each country. 
Table 4 Iceland: descriptive statistics for daily data

\begin{tabular}{|c|c|c|c|c|c|c|c|c|}
\hline Variable & $\begin{array}{c}\text { Mean no } \\
\text { controls }\end{array}$ & $\begin{array}{l}\text { Mean } \\
\text { control } \\
\text { period }\end{array}$ & $\begin{array}{c}\text { Equality in } \\
\text { means } \\
\text { t-test } \\
\text { probability }\end{array}$ & $\begin{array}{c}\text { Std. dev. } \\
\text { no } \\
\text { controls }\end{array}$ & $\begin{array}{c}\text { Std. dev. } \\
\text { no } \\
\text { control } \\
\text { period }\end{array}$ & $\begin{array}{c}\text { Equality } \\
\text { in } \\
\text { variance } \\
\text { test }\end{array}$ & $\begin{array}{l}\text { Auto } \\
\text { corr. no } \\
\text { controls }\end{array}$ & $\begin{array}{l}\text { Auto } \\
\text { corr. } \\
\text { control } \\
\text { period }\end{array}$ \\
\hline Interest rate & 13.541 & 5.933 & $0.000^{*}$ & 0.969 & 2.979 & $0.000^{*}$ & 0.998 & 0.998 \\
\hline $\begin{array}{l}\text { Change in } \\
\text { interest rate }\end{array}$ & 0.005 & -0.005 & $0.029^{*}$ & 0.067 & 0.186 & $0.000^{*}$ & -0.005 & -0.001 \\
\hline $\begin{array}{l}\text { Yield spread } \\
2 \mathrm{Y}\end{array}$ & 852.001 & 492.696 & $0.000^{*}$ & 124.559 & 210.564 & $0.000^{*}$ & 0.951 & 0.995 \\
\hline $\begin{array}{l}\text { Yield spread } \\
5 \mathrm{Y}\end{array}$ & 685.409 & 510.780 & $0.000^{*}$ & 106.513 & 141.030 & $0.000^{*}$ & 0.966 & 0.993 \\
\hline $\begin{array}{l}\text { Yield spread } \\
10 \mathrm{Y}\end{array}$ & 566.288 & 506.095 & $0.000^{*}$ & 56.699 & 100.837 & $0.000^{*}$ & 0.965 & 0.992 \\
\hline Stock returns & -0.002 & 0.000 & $0.028^{*}$ & 0.015 & 0.018 & $0.000^{*}$ & 0.240 & -0.016 \\
\hline $\begin{array}{l}\text { Exchange } \\
\text { rate changes }\end{array}$ & 0.081 & -0.006 & 0.181 & 1.995 & 1.229 & $0.000^{*}$ & 0.074 & -0.014 \\
\hline $\begin{array}{l}\text { Exchange } \\
\text { rate bid-ask } \\
\text { spread }\end{array}$ & -0.068 & -0.491 & $0.000^{*}$ & 0.010 & 0.286 & $0.000^{*}$ & 0.208 & 0.652 \\
\hline
\end{tabular}

Notes: $*$ indicates significant results at $5 \%$ level and $* *$ indicates significance at the $10 \%$ level. ${ }^{5}$ reported test is based on F-test two-tailed methodology. ${ }^{6}$ control period is from 9 October 2008 to 14 March 2017.

Table 5 Cyprus descriptive statistics for daily data

\begin{tabular}{|c|c|c|c|c|c|c|c|c|}
\hline Variable & $\begin{array}{l}\text { Mean no } \\
\text { controls }\end{array}$ & $\begin{array}{c}\text { Mean } \\
\text { control } \\
\text { period }^{10}\end{array}$ & $\begin{array}{c}\text { Equality in } \\
\text { means } \\
\text { t-test } \\
\text { probability }\end{array}$ & $\begin{array}{c}\text { Std. dev. } \\
\text { no } \\
\text { controls }\end{array}$ & $\begin{array}{c}\text { Std. dev. } \\
\text { no } \\
\text { control } \\
\text { period }\end{array}$ & $\begin{array}{c}\text { Equality } \\
\text { in } \\
\text { variance } \\
\text { test }^{9}\end{array}$ & $\begin{array}{c}\text { Auto } \\
\text { corr. no } \\
\text { controls }\end{array}$ & $\begin{array}{l}\text { Auto } \\
\text { corr. } \\
\text { control } \\
\text { period }\end{array}$ \\
\hline $\begin{array}{l}\text { Yield } \\
\text { spread 2Y }\end{array}$ & 1.783 .563 & 842.156 & $0.000^{*}$ & 473.363 & 488.587 & 0.594 & 0.988 & 0.996 \\
\hline $\begin{array}{l}\text { Yield } \\
\text { spread 3Y }\end{array}$ & 1.643 .928 & $1,450.456$ & $0.000^{*}$ & 391.194 & 321.806 & $0.007 *$ & 0.988 & 0.952 \\
\hline $\begin{array}{l}\text { Stock } \\
\text { returns }\end{array}$ & -3.666 & -0.047 & $0.003^{*}$ & 47.242 & 2.563 & $0.000^{*}$ & 0.051 & 0.183 \\
\hline
\end{tabular}

Notes: * indicates significant results at $5 \%$ level and $* *$ indicates significance at the $10 \%$ level. ${ }^{9}$ reported test is based on F-test two-tailed methodology. ${ }^{10}$ control period is from 27 of March 2013 to 6 of April 2015.

Starting with Iceland, it is true that the interest rates did not fall immediately after the imposition of capital controls as Figure 1 reveals. Taking into consideration though the results presented in Table 4 running through the whole capital control period, we can acknowledge that the interest rate declined significantly. It is also true that its level becomes more unstable but still more persistent. This is the basic difference with Cyprus where interest rates felt significantly but appear to be less variable (see paragraph 5.1). Yield spreads also become much lower but more variable. The same persistent trend is followed by all yield t-bond spreads of two, five and ten years. The exchange rate, although did not return to the pre-crisis levels, became significantly more stable. $H_{4}$ is 
confirmed. Concerning the stocks, following the literature's predictions, the burden of adjustment in asset markets falls more on prices than on quantities (Edison and Reinhart, 2000); eventually, equity prices become significantly more volatile.

Figure 5 Balance of trade chart

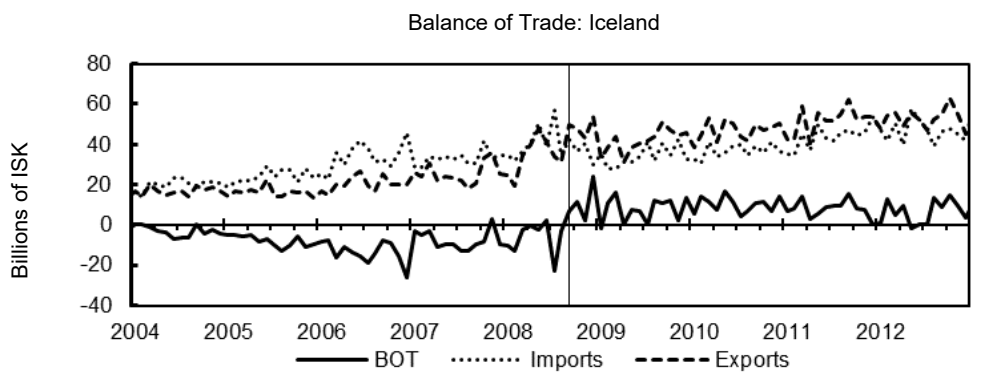

Balance of Trade: Cyprus

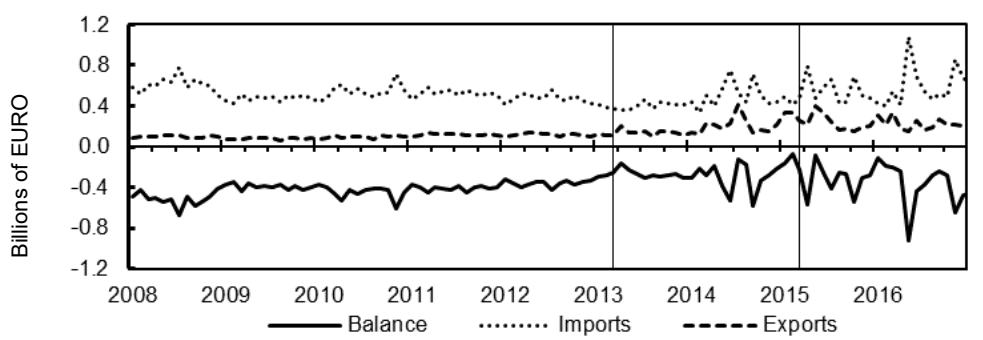

Figure 6 Iceland bid-ask spread

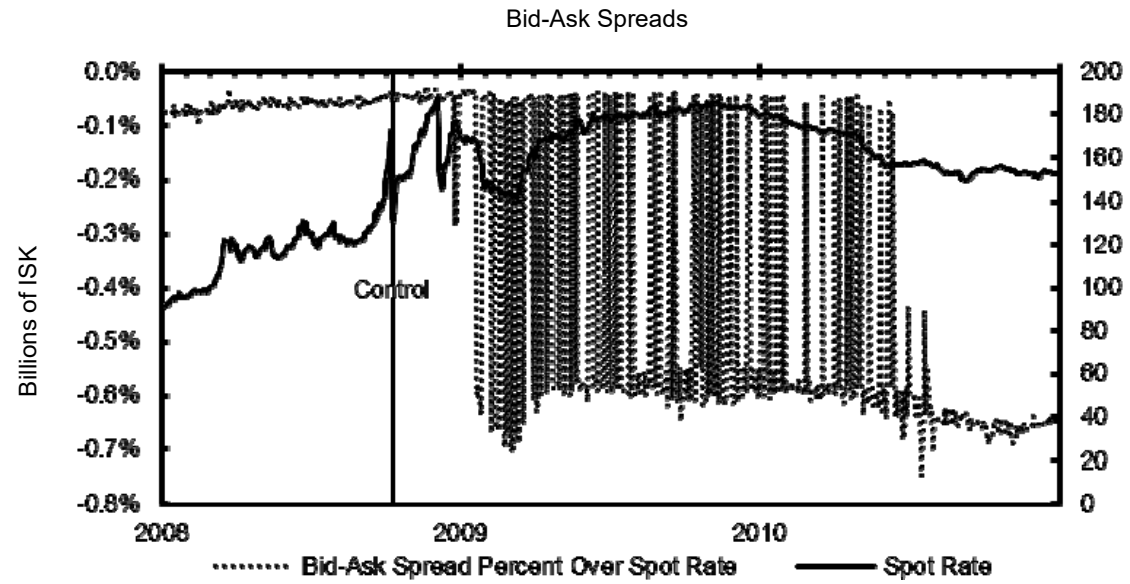

Focusing on the foreign exchange rate bid-ask spreads, results in Table 4 suggest that spreads become significantly wider and more volatile in the period after capital controls imposition. Turning to Figure 6, we acknowledge against any doubt that the bid-ask spreads are indeed more volatile if we compare them with the prior to crisis period and actually became volatile and wide in an extreme level. It should be highlighted though that after January 2009, spreads increased not due to the capital controls imposition but 
rather due to other events. Wider spreads could be linked with the reduced market liquidity but are mainly linked with the financial uncertainty that the failure of Iceland to reach a fast agreement with its creditors concerning its debt repayment have caused. The negotiations and the uncertainty continued during 2009 leading to a refusal of President Ólafur Ragnar Grímsson to counter-sign the corresponding Act of Parliament (known as the second Icesave bill) into law on 5 January 2010 and a following announcement for a referendum. The collapse of the government led to a pre-elections period and it is only after the elections held on May 2010 that spreads started to become narrower. Still volatility remained above pre-crisis levels. $\mathrm{H}_{3}$ is not confirmed.

Table 6 Quarterly capital flows (\% GDP)

\begin{tabular}{|c|c|c|c|c|}
\hline \multirow[b]{2}{*}{ Capital flow indicator } & \multicolumn{2}{|c|}{ Iceland } & \multicolumn{2}{|c|}{ Cyprus } \\
\hline & $\begin{array}{l}\text { Mean no } \\
\text { controls }\end{array}$ & $\begin{array}{l}\text { Mean control } \\
\text { period }^{11}\end{array}$ & $\begin{array}{l}\text { Mean no } \\
\text { controls }\end{array}$ & $\begin{array}{c}\text { Mean control } \\
\text { period }^{12}\end{array}$ \\
\hline Net capital flows & -0.39 & 0.05 & -0.09 & -0.05 \\
\hline Net capital inflows & 1.51 & 0.25 & 1.53 & 0.85 \\
\hline Net capital outflows & 1.11 & 0.30 & 1.45 & 0.80 \\
\hline Assets & 0.97 & -0.12 & 0.53 & -0.51 \\
\hline Direct investment & 0.24 & -0.05 & 0.44 & -0.12 \\
\hline Portfolio investment & 0.12 & -0.01 & 0.00 & -0.35 \\
\hline $\begin{array}{l}\text { Financial derivatives (other } \\
\text { than reserves) and employee } \\
\text { stock options }\end{array}$ & 0.00 & 0.01 & -0.01 & 0.17 \\
\hline Other investment & 0.56 & -0.10 & 0.10 & -0.22 \\
\hline Reserve assets & 0.05 & 0.03 & -0.01 & 0.00 \\
\hline Liabilities & 0.13 & -0.17 & 0.62 & -0.47 \\
\hline Direct investment & 0.21 & 0.03 & 0.42 & -0.10 \\
\hline Portfolio investment & 0.29 & -0.04 & 0.01 & 0.06 \\
\hline $\begin{array}{l}\text { Financial derivatives (other } \\
\text { than reserves) and employee } \\
\text { stock options }\end{array}$ & N/A & N/A & -0.02 & 0.16 \\
\hline Other investment & 0.87 & -0.16 & 0.20 & -0.59 \\
\hline Reserve assets & N/A & N/A & N/A & N/A \\
\hline Net errors and omissions & -0.18 & 0.05 & 0.00 & 0.01 \\
\hline
\end{tabular}

Notes: ${ }^{11}$ control period for Iceland is from Q4 2008 to Q1 2017. ${ }^{12}$ control period for Cyprus is from Q2 2013 to Q2 2015.

Moving our focus to Cyprus, as mentioned above, we did not have access to daily data to further analyse interest rates. Eventually, for comparison reasons we will stick to the results of the monthly data analysis presented in Section 5.1 which indicate more or less the same results with Iceland as regards interest rates. Nevertheless, the absence of an independent currency and the restricted capital mobility in Cyprus drives the economy into a paradox, given the impossible trinity and the common currency. The common currency ('fixed currency') and the restricted capital mobility allowed Cyprus to move to the direction of partially independent monetary policy which is not consistent with the European Central Bank as was previously presented in Section 2.8. Further to our 
analysis, treasury bond yield spreads between the Cypriot and the German bond become again much narrower. It is observed though that compared to Iceland's situation, 3Y spread became less volatile. This could be explained by the higher level of stability that the agreement with IMF has brought in the economy, in comparison with the complete uncertainty of the first two years of capital controls in Iceland. Equity prices in comparison to Iceland equity prices became significantly less volatile. $\mathrm{H}_{7}$ is confirmed.

The absence of daily data for Cyprus concerning the interest rates and the absence of a local currency - as highlighted above Cyprus belongs to the eurozone and does not experience foreign exchange rate pressures - does not let us compare the two countries on the same basis, in all the financial variables. Nevertheless, in the commonly presented variables, although the two countries share similar experiences when we focus on average values, surprisingly the results concerning volatility of the variables are completely different and do not follow an obvious pattern. These contradictory results in volatility make it difficult to conclude which of the two countries conformed better to the expected results as stated in the existing literature. To conclude there is no specific evidence indicating that belonging to the eurozone affects the effectiveness of controls. $H_{8}$ is not confirmed.

\section{Conclusions and further research}

The objective of the current paper was to examine whether the imposition of capital controls in Iceland and Cyprus was effective and in accordance to the results predicted by the existing literature. Both countries used measures during a period of extreme turbulence and it is rather hard to distinguish which part of the effects on financial variables is due to capital controls and which is due to financial crisis. Our research hypotheses results are summarised in Table 7.

Table 7 Summary of conclusions

\begin{tabular}{lcc}
\hline Ho Hypotheses & Iceland & Cyprus \\
\hline The controls reduced the volume of capital flows & Yes & Partially \\
The controls altered the composition of capital flows & Yes & Yes \\
The controls reduced real exchange rate pressures & No & N/A \\
The controls made monetary policy independent & Yes & Yes \\
Belonging to a monetary union is a negative factor for success & N/A & No \\
\hline
\end{tabular}

In general controls were only partially effective and there is no clear evidence which of the two countries performed better. A significant drop of the interest rates was witnessed indicating that both countries achieved an increase in the level of monetary policy independence. A decrease of Cyprus' onshore-offshore interest rates spreads was observed. Although the overall outflows in both countries as a percentage of GDP have been reduced, foreign exchange reserves and deposits in Cyprus continued to drop, indicating a partial failure to block effectively the outflows. Controls succeeded to alter the composition of private capital flows resulting to different percentages as part of GDP in each country. In Iceland controls failed to reduce the pressures over the exchange rate and the bid-ask spreads widened. It is possible that the delayed reforms of the Icelandic 
economy contributed to this outcome. Belonging to the eurozone was not proven to be a negative factor for the success of the measures in Cyprus.

According to Edison and Reinhart (1999) capital controls when applied, introduce a systematic wedge between domestic and foreign interest rates. Domestic interest rates will decline since there is no need for high rates to prevent capital outflows. Given this expectation, it is interesting to evaluate the differences between domestic and foreign interest rates in Iceland. In addition, further focus could be set on how capital controls affect the volatility of interest rates and stock returns. To analyse whether a change in volatility took place during the capital control episodes, a variety of generalised autoregressive conditional heteroscedasticity (GARCH) models could be applied as in Edison and Reinhart (1999). Finally it will be interesting to examine the effectiveness of controls in Greece versus Cyprus and compare the influence of the EU operating framework.

\section{References}

Alderman, L. (2017) Iceland, a Symbol of Financial Crisis, Finally Lifts Capital Controls, 14 March, The New York Times, New York, NY.

Bakker, A.F. (1996) The Liberation of Capital Movements in Europe, Kluwer Academic Publishers, Dordrecht.

Baldursson, F. and Portes, R. (2013) Gambling for Resurrection in Iceland: The Rise and Fall of the Banks, CEPR Discussion Paper 9664, September.

Burda, M. and Wyplosz, C. (2005) Macroeconomics: A European Text, Oxford University Press, Oxford.

Edison, H. and Reinhart, C. (2000) Capital Controls During Financial Crisis: The Case of Malaysia and Thailand, International Finance Discussion Papers, Board of Governors of the Federal Reserve System, March.

ESM (2017) What Was the Private Sector Involvement (PSI) in Greece? [online] https://www.esm.europa.eu/content/what-was-private-sector-involvement-psi-greece (accessed 22 May 2017).

Europa.eu. (2012) 'Consolidated versions of the treaty on European Union and the Treaty on the Functioning of the European Union, 26 October [online] http://eur-lex.europa.eu/ legal-content/EN/TXT/PDF/?uri=CELEX:12012E/TXT \& from=EN (accessed 23 May 2017).

Haldane, A.G. (2011) 'The big fish small pond problem', Annual Conference, Institute for New Economic Thinking, Bretton Woods New Hampshire, 9 April.

IMF (2015) Iceland. Selected Issues, IMF Country Report No. 15/73, March.

IMF Strategy, Policy, and Review Department (2011) Recent experiences in recent in managing capital inflows - cross-cutting themes and possible policy framework', International Monetary Fund.

Linklaters (2013) 'Capital and exchange controls', Eurozone Bulletin, April, No. 3, pp.6-7.

Magud, N.E., Reinhart, C.M. and Rogoff, K.S. (2011) Capital Controls: Myth and Reality - A Portfolio Balance Approach, NBER Working Paper Series, February.

Marston, R.C. (1995) International Financial Integration: A Study of Interest Differentials between the Major Industrial Countries, Cambridge University Press, Cambridge, UK.

Mishkin, F.S. (1998) International Capital Movements, Financial Volatility and Financial Instability, NBER Working Papers, 6390, January.

Neely, C.J. (1999) An Introduction to Capital Controls, Federal Reserve Bank of St. Louis.

OECD (2014) Asset/Liability versus Directional Presentation, OECD. 
RICS (2012) RICS Cyprus Property Index Q4 2012 [online] http://www.rics.org/gr/knowledge/ market-analysis/rics-cyprus-property-price-index/ (accessed 21 May 2017).

Sewell, M. (2011) Characterization of Financial Time Series, UCL, Department of Computer Science, London.

Strupczewsk, J. and Breidthardt, A. (2013) Last-Minute Cyprus Deal to Close Bank, Force Losses [online] http://Ekathimerini.com (accessed 21 May 2017).

The Economic Times (2015) Greece: How Capital Controls Worked in Cyprus, 28 June [online] $\mathrm{http}: / /$ economictimes.indiatimes.com/articleshow/47855780.cms?utm_source=contentofinteres t\&utm_medium=text\&utm_campaign=cppst (accessed 22 May 2017).

The Economist (2008) Cracks in the Crus [online] http://www.economist.com/node/12762027 (accessed 22 May 2017).

The Global Economy (2017) Cyprus: Economic Growth, Cyprus GDP Growth Rate [online] http://www.theglobaleconomy.com/Cyprus/ (accessed 22 May 2017).

Wilson, J. (2012) Cyprus Requests Eurozone Bailout, 25 June, The Financial Times, London, UK.

Wolff, G. (2013) Capital Controls Will Put the Euro at Risk, 25 March, The Financial Times, London, UK.

World Bank (2017) Bank Nonperforming Loans to Total Gross Loans (\%) [online] http://data.worldbank.org/indicator/FB.AST.NPER.ZS (accessed 22 April 2017).

\section{Notes}

1 It should be underlined that Cyprus and Iceland, both carrying financial sector distortions, were heavily disoriented by the large international capital inflows that the prosperous stable economic period of Europe have offered during the start of the new millennium. By using this low cost funding, both countries' banks expanded disproportionally reaching operations that surpassed multiple times both countries GDP and that generated risky loans. Leman brothers' failure created multiple side-effects including large outflows from both countries that led to the imposition of capital controls as a last resort measure before the total collapse.

2 E.g., longer maturity flows, share of FDI, debt, etc. 